\title{
PROGRESS IN FOREST FIRE PREVENTION ${ }^{1}$ BY G. W. I. CREIGHTON ${ }^{2}$
}

G. W. I. Creighton is a native Nova Scotian. He studied forestry at the University of New Brunswick and was employed for a short time by the International Paper Company, the Federal Forest Service, and for two years by the Laurentide Division, Canadian Power and Paper Company, which is now the Consolidated Paper Company. He spent nearly three years in Europe studying European forestry methods and has been with the Nova Scotia Government since 1934.

Canada is a big country with such a variety of conditions that it would be a difficult task to cover the subject, "Progress in Forest Fire Prevention", in one short paper, even if one had the knowledge necessary to make the attempt.

Since we have at this meeting many persons well qualified to speak on the subject, I will confine my remarks to my own Province.

In Nova Scotia, serious losses from forest fires bave been recorded over a long period, and apparently the first attempt to prevent losses from forest fires was made in 1761. In that year, the Government at Halifax passed legislation entitled, "An Act for Preventing Damages by Unseasonable Burning or Firing of the Woods".

This Act provided that the Grand Jury at the March Sessions should make regulations with the approbation of the Justices for the Province. Regulations were to remain in effect for 12 months and were to be renewed annually.

Penalties imposed on persons who neglected or refused to obey the regulations were to be set by the Magistrates but were not to exceed $£ 5$, and any prosecution for an offence against the Act had to be commenced and prosecuted within the space of three months after the offence was committed.

In 1864 a Section appears in the Act: "If any person convicted under this Chapter shall not pay the penalty and costs, and shall have no goods whereon a levy can be made, he may be imprisoned for a term not exceeding one day for every dollar of the amount of the judgment unless the same shall be sooner paid".

By 1873 , the penalty was increased to $\$ 80.00$ and the following Section added: "Any person violating the provisions of this Chapter shall be liable to the person injured for all damage resulting from such violation".

In the Revised Statutes of 1884, Chapter 65, "Protection of Woods Against Fire", the provisions of the Act are set out in twenty-three Sections. Here for the first time restrictions are imposed on railway locomotives, and the duty of engine drivers is defined.

The Municipal Councils are given authority to put in force fire regulations and the Act states: "It shall be the duty of all County Councillors, Stipendiary Magistrates, Justices of the Peace and other County Officers, and the special duty of all Deputy Surveyors and other officers of the Department of Crown Lands, and Chief and other Game Commissioners, and of all Game Wardens to enforce the provisions and requirements of the Chapter."

\footnotetext{
${ }^{1}$ Paper presented at the 1955 Annual Meeting of the C.I.F. held at Saskatoon, Sask.

${ }^{2}$ Deputy Minister of Lands \& Forests, Noya Scotia.
} 
In view of later developments, it is interesting to note that the Department of Crown Lands, the forerunner of the Department of Lands and Forests, is mentioned for the first time.

The next important change in the Act came in 1904 when provision was made for the appointment of Fire Rangers, and the duties of Rangers are set out in detail.

Although fire protection remained a Municipal responsibility, the Rangers were appointed by the Governor-in-Council, and were to submit an annual report to the Commissioner of Crown Lands.

The Rangers were paid an annual retainer by the Province, and a daily wage by the Municipality.

In order to provide the necessary funds, the Municipal Assessors were given authority to levy a tax of $1 / 4$ cent per acre on all timber holdings of 1,000 acres or more, and if this proved insufficient, the Municipalities were authorized to make up the difference out of general funds.

Burning without a permit was prohibited during the period from April 15 th to December 1st, and during the same period it also became necessary to obtain a permit to operate a portable steam engine within 60 rods of the woods.

While restrictive legislation had been in force for over one hundred and forty years, legislation alone had not prevented fire losses, but the appointment of Fire Rangers now made the legislation useful.

Unfortunately, public opinion was not yet very strong; lumbering was still considered a temporary phase which preceded settlement, and the newly appointed rangers had no equipment to combat fires. Some rangers were energetic, but as a rule little effort was made either to prevent or combat fires unless buildings were endangered.

During the next decade some progress was made, and the Fernow Report, "Forest Conditions of Nova Scotia", which was prepared during 1909 and 1910, and published in 1912, undoubtedly had a marked effect on public opinion. Dr. Fernow reported that one-quarter of the forest area was fire barren, and he wrote as follows:

"The first, most needful step towards a change from past neglect has already been taken in the enactment of legislation to protect the forest properties against fire, and in inaugurating the beginning of a suitable organization for carrying out its provisions in co-operation between the Government and the timberland owners. This organization should be extended and perfected until the fire danger to forest property has become as remote as to city property. This is practically possible in Nova Scotia, where the populational conditions are most favorable, inasmuch as the country is almost everywhere settled and accessible, and owners of woodlots or small timber tracts are distributed throughout the country. Fire watchers and fire fighters are, therefore, nearly everywhere available on short notice. There is no reason why in a few years of earnest and determined effort, by an educational campaign and by efficient protective service, the destruction of forest by fire should not be reduced to a rare accident. Only when this is accomplished will it be reasonable to resort to methods of recuperation. 
"To further reduce the chance of destructive fires, the propriety of lopping tops in logging operations, if not burning the same, as a reasonable protective measure, should be seriously considered.

"As to details of practicable measures in this direction and otherwise, I may refer to a report by the Committee on Forest Fire Legislation of the Canadian Forestry Association, lately issued.

"I would recommend its study especially with regard to the provisions for making land along railways safe and the railways liable for the fires they set out, and also as regards suggestions with respect to the erection of watch towers, the issue of permits for setting fires in the woods, the lopping of tops, the burning of brush, and the proper organization of a fire fighting force."

The report, "Forest Protection in Canada 1913-1914", compiled under the direction of Clyde Leavitt, Chief Forester, Commission of Conservation, and Chief Fire Inspector, Board of Railway Commissioners, describes conditions at that time and indicates a growing interest in fire prevention. Referring to the season of 1914, the report states:

"The losses caused by fire over the whole Dominion were considerable, and there is no doubt that the losses along railway lines would have been very much greater had it not been for the prevention measures taken by the railways and by the Dominion and Provincial agencies co-operating with them."

Those sections of the report dealing directly with Nova Scotia indicate that Dr. Fernow's recommendations had not been adopted as yet, but some little progress was apparent.

Forest fire losses were compiled and published in the report of the Department of Crown Lands in 1915, and have been compiled and published ever since.

In the year 1926, the foundation was laid for a modern and efficient protection service when the Departments of Crown Lands, and Forests and Game, were merged and became the Department of Lands and Forests. In that year Fire Rangers were engaged by the Province on a full time basis, and the Province assumed the responsibility of protecting all forest land, private as well as public.

Rangers were now provided with needed equipment, fire towers were built, and an effort was made to reduce fire hazards.

Increased efforts were made to mould public opinion, with special attention paid to Boy Scouts and School children.

In the past ten years, more progress has been made than in any other similar period. The permanent staff of Foresters and Rangers has been vastly increased, more and better fire fighting equipment has been purchased, new fire towers have been built and an aerial patrol organized. Daily weather reports are received from the Dominion Public Weather Office, which make possible advance planning. In hazardous periods, fire fighting personnel may be alerted, and when deemed advisable, the woods closed to public travel. More time and money is allotted to the task of educating the public and the public in turn has become increasingly concerned over the welfare of our forests. 
In spite of increased efforts to prevent and combat fire, serious losses are still suffered every year, although a gradual reduction is apparent.

At the present time we have a good supply of fire fighting equipment, good coverage by fire towers and aerial patrol, a loyal and efficient force of Rangers, and a growing public opinion. What then is needed to further reduce fire losses?

In Nova Scotia, few fires start from lightning, and probably $99 \%$ of all forest fires are of human origin. Fire prevention then must be the weakest link in our chain of protection.

Formerly, railways, portable mills and settlers' brush fires caused most of our fire losses.

The enforcement of existing regulations has reduced fires from these sources to a minimum, and we have reason to hope, therefore, that fires from other causes may also be eliminated.

Fires started by careless campers, fishermen, smokers and children, together with a few incendiary fires, cause most of our present-day losses.

Many fires could be prevented if we could eliminate fire hazards. As in Dr. Fernow's time, logging slash is still a serious problem, but except along railways and public highways, little attempt has been made in Nova Scotia to remove slash, either by burning or lopping, though I believe great strides have been made in other Provinces. In time, closer utilization undoubtedly will correct this situation, but no great improvement in that direction can be foreseen in the immediate future.

Undoubtedly the strongest weapon at our disposal is public opinion, and this must be strengthened by every possible means.

If public opinion were so strong that a person who started a fire became a social outcast, forest fire losses in Nova Scotia would be negligible.

It is evident, then, that we must redouble our efforts to impress on the general public the need for greater care with fire.

To be fully effective, such an effort must be organized on a national scale and planned as a long-term project. Federal and Provincial authorities, together with private organizations, companies, and individual land owners, must join together in a carefully planned, well organized and sustained plan of fire prevention, using the press, radio, motion pictures, television, public speakers and every other means at our disposal. 